\title{
David Martin's The Religious and the Secular (1969): an Underestimated Masterwork in the Study of Western Secularization
}

\author{
Sam Brewitt-Taylor ${ }^{1}$ \\ Published online: 13 March 2020 \\ (C) The Author(s) 2020
}

\begin{abstract}
This article considers the content and reception of David Martin's The Religious and the Secular (1969), a brilliant text whose revolutionary implications were overlooked by most of the next two generations of secularization scholarship because it was so far ahead of its time. The young Martin was able to unmask the ideological nature of the secular project partly due to his knowledge of theology, partly due to his eclectic reading, and partly because he was writing at a time when secularity was only just achieving cultural hegemony in Anglophone cultures. Fifty years later, now that postsecular scholarship is beginning to deconstruct the secular project, Martin's anthology re-emerges as a vital early text in the new paradigm in secularization studies.
\end{abstract}

Keywords Secularization $\cdot$ Secularity $\cdot$ Postsecular $\cdot$ Secular revolution $\cdot$ David Martin

\section{Introduction}

The 2020 s are an exciting time to be studying secularization: after several false starts, we might finally be witnessing the emergence of a new paradigm. Since the 1960 s, Western sociologists and historians have routinely told the "secular" story about secularization, in which "religion", once ubiquitous and powerful, became in some countries steadily less influential, thus prompting the emergence of "secular" societies, which have no particular collective ideology. ${ }^{1}$ For half a century, this basic framework dominated the debate, underpinning a wide

\footnotetext{
${ }^{1}$ The secularization literature expresses its "no collective ideology" claim by characterizing secularity as either post-ideological "rationality" or postideological "personal autonomy". See for examples Bryan Wilson, Religion in Secular Society: Fifty Years On, ed. Steve Bruce (Oxford: OUP, 2016), 3; Callum Brown, The Death of Christian Britain: Understanding Secularisation 1800-2000 (Abingdon: Routledge, 2001), 193-4; Steve Bruce, Secularization: In Defence of an Unfashionable Theory (Oxford: OUP, 2015), 55. The connection between "secularization" and "end-of-ideology" discussions was brilliantly made by David Martin, "Some Utopian Aspects of the Concept of Secularization", in idem, The Religious and the Secular (London: Routledge \& Kegan Paul 1969), 23-36, 24.
}

Sam Brewitt-Taylor samuel.brewitttaylor@gmail.com

Extended author information available on the last page of the article variety of scholarly disagreements about the extent, timing, and causes of "secularization" in particular historical cases. ${ }^{2}$ Recently, however, a distinctively "postsecular" theory of secularization has emerged, inspired by the postcolonial turn, which radically decentres Western secularity by historicizing its central categories. ${ }^{3}$ For proponents of this perspective, the whole concept of "religion" is analytically suspect. ${ }^{4}$ Far from being a real global phenomenon, "religion" is actually secularity's

\footnotetext{
$\overline{{ }^{2} \text { For this model }}$ shared amongst varied theorists, see Wilson, Religion in Secular Society, 6; Peter Berger, The Sacred Canopy: Elements of a Sociological Theory of Religion (Garden City, NY: Doubleday, 1967), 107; Callum Brown, Becoming Atheist: Humanism and the Secular West (London: Bloomsbury, 2017), 4.

3 "The postsecular turn essentially symbolizes... a move towards problematizing and critically interrogating the natural status ascribed to secularity": Umut Parmaksız, "Making Sense of the Postsecular", European Journal of Social Theory, Vol. 21, No. 1 (Feb., 2018): 106.

${ }^{4}$ For postsecular critiques of the concept of "religion", see of many examples Jonathan Z. Smith, Imagining Religion: From Babylon to Jonestown (Chicago: University of Chicago Press, 1982), xi; Talal Asad, "The Construction of Religion as an Anthropological Category," in his Genealogies of Religion: Discipline and Reasons of Power in Christianity and Islam (Baltimore: Johns Hopkins University Press, 1993), 27-54, 29; Richard King, Orientalism and Religion: Postcolonial Theory, India, and the "Mystic East" (London: Routledge, 1999), ch. 2; Timothy Fitzgerald, The Ideology of Religious Studies (Oxford: OUP, 2000); Daniel Dubuisson, The Western Construction of Religion: Myths, Knowledge, and Ideology (Baltimore: Johns Hopkins University Press, 2003); William Cavanaugh, The Myth of Religious Violence: Secular Ideology and the Roots of Modern Conflict (Oxford: OUP, 2009), ch. 2.
} 
othering category, used by secular theorists to designate all cultures that are not secular, as Britons might talk of "foreigners" or ancient Greeks of "barbarians". Instead, secularity is best understood as an ideological culture in its own right, comparable to Christianity and Islam, dominant in most Western cultures since the 1960s, which claims to represent post-ideological neutrality, which asserts its uniqueness by labelling all other cultures "religion", and within which most of the last half-century of the Western secularization debate has been more-or-less naively situated. ${ }^{5}$ Thus the theoretical question at the crux of the secularization debate is whether secularity's claims to exceptional post-ideological neutrality should be endorsed or historicized: "secular" approaches are those written within the culture of secularity, which opt for endorsement, and "postsecular" approaches are those written from an external perspective, which opt for historicization. From a postsecular perspective, therefore, "secularization" is properly understood as the rise of secularity, a culturally-specific phenomenon analogous to "Christianization" and "Islamization", which is not to be confused with the quite different phenomenon of "Christian decline". ${ }^{6}$ On this view, the key to explaining secularization is to conceptualize it as the acceptance and enactment of secularity's beliefs: but whereas theistic beliefs make theological claims about the uniqueness of God, secularity's beliefs make sociological claims about the uniqueness of secular societies, especially their exceptional neutrality, permanence, and modernity - beliefs which, by assigning epistemic privilege to the culture of secularity, cause those who accept them to think and act in culturally distinctive ways. The task for postsecular historians of secularization, consequently, is to understand when and why some groups of people began believe that they lived in a permanently post-"religious" age, and how this belief radically reshaped their thoughts and actions. ${ }^{7}$

Yet as this fledgling paradigm gains self-consciousness, its proponents are beginning to realize that it is not as new as one might think: many of its constituent elements have in fact already been articulated by central figures in the culturalist tradition in Western sociology, especially by Max Weber and the mature Émile Durkheim, who turn out on closer inspection not to have been paid-up

\footnotetext{
5 Parmaksız, "Making Sense of the Postsecular", 109.

${ }^{6}$ Ibid. For a worked example of this model, see Sam Brewitt-Taylor, "Notes Toward a Postsecular History of Modern British Secularization”, forthcoming.

${ }^{7}$ For an initial attempt at this in the British case, see Sam Brewitt-Taylor, "The Invention of a 'Secular Society'? Christianity and the Sudden Appearance of Secularization Discourses in the British Media, 1961-64", Twentieth Century British History, Vol. 24, No. 3 (2013): 327-350; idem., Christian Radicalism in the Church of England and the Invention of the British Sixties, 1957-1970 (Oxford: OUP, 2018).
}

secularization theorists after all. ${ }^{8}$ Consequently, a crucial dimension of this postsecular paradigm's theoretical development is the discovery of its intellectual heritage, so that its proponents can learn from that heritage whatever lessons they can. ${ }^{9}$

This essay pursues this agenda by considering the content and reception of David Martin's The Religious and the Secular, a brilliant anthology of articles and occasional pieces on secularization written in the mid- and late 1960s and published as a book in 1969. The essay's central thesis is that the young Martin successfully deconstructed the entire secularization paradigm by critiquing the central categories in which it was expressed, such that his anthology should be regarded as a vital early text in the new paradigm in secularization studies. ${ }^{10}$ The essay's second thesis is that the widespread neglect of Martin's critique in subsequent scholarship, to the point where Martin himself chose not to develop its more radical implications in his middle-period work, illustrates the extraordinarily powerful hold of secularity's ideological assumptions on Western secularization scholarship from the late 1960s to the early $2000 \mathrm{~s} .{ }^{11}$ It is only in the twenty-first century, now that world events are beginning to disenchant secularity, that postsecular scholarship is able to decentre and historicize secularity, and return Martin's early critique to its rightfully central place in the Western secularization literature. ${ }^{12}$

As devotees of Martin's work will have noted, this argument trespasses on the disputed question of how to contextualize The Religious and the Secular in Martin's overall

\footnotetext{
${ }^{8}$ For these thinkers not being secularization theorists, see J.C.D. Clark, "The Re-Enchantment of the World? Religion and Monarchy in Eighteenth-Century Europe", in Michael Schaich, ed., Monarchy and Religion: The Transformation of Royal Culture in Eighteenth-Century Europe (Oxford: OUP, 2007), 45-49; Peter Ghosh, Max Weber and the Protestant Ethic: Twin Histories (Oxford: OUP, 2014), 270, 290; Lise Ann Tole, "Durkheim on Religion and Moral Community in Modernity", Sociological Inquiry, Vol. 63, No. 1 (Jan., 1993): 2

${ }^{9}$ As Martin noted, Western secularization scholarship is not very good at situating itself within the previous history of the field: David Martin, The Education of David Martin: The Making of an Unlikely Sociologist (London: SPCK, 2013), 134.

${ }^{10}$ Whilst Martin deliberately disassociated himself from the term "postsecular", by this term he meant Jürgen Habermas' claim that Western societies now live in a "postsecular age". This claim is independent of the "strong" postsecular perspective adopted here, in which the term "postsecular" refers to a theoretical stance which seeks to deconstruct secular ideology: David Martin, Religion and Power: No Logos Without Mythos (Farnham: Ashgate, 2014), 14.

${ }^{11}$ This neglect is also discussed by Paolo Costa, but this essay explains it differently by focusing on the specific cultural context of the late twentiethcentury West: Paolo Costa, "The One and the Many Stories: How to Reconcile Sense-Making and Fact-Checking in the Secularization Narrative", in Hans Joas, ed., David Martin and the Sociology of Religion (Abingdon: Routledge, 2018), 50-66. More widely, this essay understands Martin's 'middle period' to last from 1968 to 1986 , the year when he decisively took his global turn, resulting in his path-breaking studies of Pentecostalism. For 1986 (but also the precursors beforehand) see Martin, Education of David Martin, 195.

${ }^{12}$ See for example William Keenan, "Post-Secular Sociology: Effusions of Religion in Late Modern Settings", European Journal of Social Theory, Vol. 5, No. 2 (May, 2002): 289.
} 
intellectual trajectory. ${ }^{13}$ The cartoon version of Martin's early intellectual biography is that he called for the elimination of the concept of "secularization" in 1965, and then performed a radical self-contradiction by publishing "Notes for a General Theory of Secularization" in 1969, and developing this into his A General Theory of Secularization (1978). Martin himself regularly expressed irritation at this account, insisting throughout his later career that his "conceptual critiques" of 1964-69 and his General Theory were in fact closely related. A central purpose of those critiques, he repeatedly explained, was to purge the term "secularization" of its teleological overtones, thus paving way the way for the much more contingent and historically-nuanced account of Western secularization that he mooted in 1969 and delivered in $1978 .{ }^{14}$ And indeed The Religious and the Secular does perform precisely this function, such that Martin was quite right to insist that positive links existed between his 1969 The Religious and the Secular and his 1978 General Theory. ${ }^{15}$ At the same time, the essays in Part One of The Religious and the Secular mounted a deeper critique of "secularization", going beyond the critique of teleology to deconstruct the concept itself. It is this early and more radical approach that this essay seeks to recover. ${ }^{16}$

\section{Martin's Radical Critique of "Secularization"}

David Martin first became seriously interested in secularization theory in 1964, the same year that he took his $\mathrm{PhD}$ in sociology. ${ }^{17}$ It used to be thought that the roots of widespread Western secularization go back to the dawn of industrialization, but recent revisionism has conclusively established that Anglosphere societies, at least, did not experience a "secular

\footnotetext{
${ }^{13}$ In particular, this account occupies a middle position between the "cartoon" version on the one hand, which exaggerates the break between Martin's early and middle- period work, and Anthony Carroll's account on the other, which in this essay's view exaggerates the continuities: Anthony Carroll, "David Martin's Theory of Secularization", in Hans Joas (ed.), David Martin and the Sociology of Religion (London: Routledge, 2018), 16-31.

${ }^{14}$ David Martin, "The Secularization Issue: Prospect and Retrospect", The British Journal of Sociology, Vol. 42, No. 3 (Sep., 1991): 467; David Martin, "What I Really Said About Secularization", Dialog: A Journal of Theology, Vol. 46, No. 2 (Summer, 2007): 145; Martin, Education of David Martin, 131.

${ }^{15}$ Indeed, the dust-jacket to the original 1969 Routledge \& Kegan Paul edition of The Religious and the Secular characterizes the work exactly as Martin did in his middle period: "The author claims that secularization could be a useful concept were it not confused by overtones from the philosophy of history or carelessly appropriated by existentialist theologians". In particular, Martin's 1968 essay "The Secularization Pattern in England", included in The Religious and the Secular, is a clear precursor of the 1978 General Theory.

${ }^{16}$ Martin conceded that some tension exists between these two approaches in the preface to his 1978 General Theory, where he explained that "a new turn in my thinking occurred when I wrote 'Notes towards a general theory of secularization"". The "tensions" between deconstructing the language of secularization and using "secularization" as an analytical category, he insisted, "need to be held": Martin, General Theory of Secularization, viii.

${ }^{17}$ For 1964, see Martin, "What I Really Said About Secularization”, 139.
}

revolution" until the 1960s, such that Martin was in fact writing right in the middle of the events that he analysed. ${ }^{18}$ In the 1940s and early 1950s, during the Second World War and the early Cold War, Christianity had enormous public salience, especially since Western rhetoric frequently framed the early Cold War as a spiritual conflict between a Christian (sometimes "Judeo-Christian") West and a secular Soviet Union: the phrase "In God We Trust", for example, was added to American banknotes from $1957 .{ }^{19}$ As far as we can tell from the available data, at least $90 \%$ of the populations of Anglosphere societies personally identified as Christians: those positively self-identifying as having "no religion", by contrast, numbered "a tiny proportion, usually less than 1 per cent, and rarely more than 2 per cent, of the population of Western nations". ${ }^{20}$ Faced with a Soviet enemy that claimed to be post-ideological, Anglosphere public discussion routinely insisted that post-ideological societies were impossible: instead, it was frequently argued, if a society abandoned its "religion", it would necessarily end up embracing some form of totalitarian religion-substitute, as had apparently happened in Hitler's Germany and Stalin's USSR. ${ }^{21}$ For this reason, the "secular revolution" that occurred in Western societies in the 1960s was a profoundly radical cultural transformation. Almost overnight, many Western Anglophone commentators suddenly became convinced, not only that permanently postreligious societies were possible, but that they had long been living in one, and that Western culture ought to be reconfigured accordingly. ${ }^{22}$

By the time that Martin published his first work on the subject in 1965, however, the secular revolution was only in its infancy: the teleological metanarrative of "secularization" was still being popularised largely by radical Christian theological works, especially by E.R. Wickham's Church and People in an Industrial City (1957), John A.T. Robinson's Honest to God (1963), and Harvey Cox's The Secular City (1965); the foundational sociological works, Bryan Wilson's Religion in Secular Society (1966) and Peter Berger's The Sacred Canopy (1967), still lay in the future. ${ }^{23}$ Since the idea

\footnotetext{
${ }^{18}$ By "Anglosphere" this essay means Britain, Canada, the United States, Australia, and New Zealand. The concept of a "secular revolution" was coined in Callum Brown, Religion and the Demographic Revolution: Women and Secularisation in Canada, Ireland, UK, and USA since the 1960s (Woodbridge: Boydell, 2012), 252.

${ }^{19}$ Dianne Kirby, ed., Religion and the Cold War (Basingstoke: Macmillan, 2003); Jonathan Herzog, The Spiritual-Industrial Complex: America's Religious Battle Against Communism in the Early Cold War (Oxford: OUP, 2011), 5 .

${ }^{20}$ Brown, Religion and the Demographic Revolution, 62.

${ }^{21}$ Brewitt-Taylor, "Postsecular History of Modern British Secularization".

${ }^{22}$ For this phenomenon in England, see Simon Green, The Passing of Protestant England: Secularization and Social Change, c.1920-1960 (Cambridge: CUP, 2012), 294.

${ }^{23}$ Cf. David Martin, "On Secularization and its Prediction: A SelfExamination", in Grace Davie, Linda Woodhead, and Paul Heelas, eds., Predicting Religion: Christian, Secular and Alternative Futures (Aldershot: Ashgate, 2003), 33.
} 
of "secularization" as the death of collective ideology had not yet been profoundly normalized, since he possessed considerable familiarity with theology, and since his sociological reading had been unusually wide and autodidactic, the young Martin was able to use his outsider's perspective to critique the secularization paradigm to its very foundations. ${ }^{24}$

The result was "Towards Eliminating the Concept of Secularization" (1965), which damningly critiqued teleological accounts of secularization, but also made the more radical move of deconstructing the notion of "secularization" altogether. Martin began his deconstruction by arguing that the newly commonplace practice of defining "secularization" as the epochal decline of "religion" was "conceptually confused", because its notion of "religion" was intrinsically incoherent. ${ }^{25}$ By invoking "the decline of religious institutions considered as a class", he argued, the secularization paradigm was assuming that "religion" was a coherent category - that "religious groups undergo a common process because they share certain common denominators". ${ }^{26}$ The central problem, therefore, was to establish whether these "common denominators" could in fact be identified. Anticipating the postsecular turn by four decades, Martin answered this question firmly in the negative: the global cultural entities commonly classified as "religions", he argued, are all so different that what is "religion" for one culture is often not "religion" for another, and consequently establishing an objective definition of "religion" is impossible: "no sets of [universal] criteria", he insisted, "can be utilized to distinguish between the religious and the secular". ${ }^{27}$ There is, for example, a "Catholic definition of religion", which "lays stress on membership of (or relation to) an institution", and a rival "Protestant definition of religion" which focusses on belief, though on which precise beliefs is disputed by Protestants amongst themselves. Whilst it might seem tempting simply to follow local usage, this approach runs into fatal difficulties in cultures that do not possess a category of "religion" at all, such as ancient Greece. ${ }^{28}$ Consequently, Martin insisted, the whole idea of "secularization" as "the decline of religious institutions considered as a class" did not make sense; it was "an unfortunate usage", which "might just as well be dropped". 29 "The most important point which I would wish to urge is that there is no unitary process called 'secularization' arising in reaction to a set of characteristics labelled 'religious'. It can be shown that religious institutions bear no such common characteristics." ${ }^{30}$ Why, we might ask, developing this line of argument, do we

\footnotetext{
24 Ibid, 31.

25 David Martin, "Towards Eliminating the Concept of Secularization", in idem., The Religious and the Secular, 10.

${ }^{26}$ Ibid, 15. Italics in the original.

27 Ibid, 13.

28 Ibid, 14.

29 Ibid, 15.

30 Ibid, 16.
}

discuss "secularization" whilst including Theravada Buddhism but not Leninism into the category of "religion"? Why are we insisting on placing upwards of $84 \%$ of today's humanity, and upwards of $95 \%$ of humans who have ever lived, in the same category at all? $?^{31}$ On this approach, whilst one can coherently talk of the decline of Christianity, it makes no sense to talk of the decline of "religion", just as it makes no sense to talk of the decline of "foreigners", because there is no reason to think that the entities being referred to actually have anything in substantive common with each other. ${ }^{32}$ In a later essay, Martin succinctly summarized this position by referring to "the impossibility of defining secular based on the longdiscussed difficulty of defining religion". ${ }^{33}$ "Since there is no unitary process of secularization", he concluded, "one cannot talk in a unitary way about the causes of secularization". ${ }^{34}$

Yet if the conventional vision of "secularization" as the decline of "religion" makes no sense, this raises the question of why so many people think that it does, and here Martin put his finger squarely on the issue, moving his critique onto a second level. "The whole concept [of secularization]", he suggested, "appears as a tool of counter-religious ideologies". 35 These secular ideologies identify "the 'real' element in religion" so that they can define themselves in contradistinction to it, and define what they oppose as irreversibly declining, "partly for the aesthetic satisfactions found in such notions and partly as a psychological boost to the movements with which they are associated". ${ }^{36}$ Developing Martin's argument, we might say that secular cultures use "religion", as British nationalists use the term "foreigners", to define themselves in mirror-image by publicly declaring what they are not. In particular, Martin insisted, secular ideologies indirectly depict their own beliefs as "natural" by insisting on the "artificiality" of non-secular beliefs, which can then, in a "pejorative usage", be defined as ever-declining "religion". ${ }^{37}$ Rationalist secularization theories especially, he felt, begin by defining "religion" as beliefs "which by nature cannot be proved", as a way of emphasizing the assured scientific verifiability of secular "truth". Secularity's vision of the decline of "religion" was therefore actually secularity's mirror-image way of describing "the triumph of truth", which "will be manifest in the demise

\footnotetext{
${ }^{31}$ For $84 \%$, see Pew Foundation, "The Global Religious Landscape," [http:// www.pewforum.org/2012/12/18/global-religious-landscape-exec/], accessed 13 April 2017. The 95\% figure is the author's calculation based on 107 billion humans having ever lived, of which 80 billion lived before 1500, and 8 billion being alive today. For these numbers, see Population Research Bureau, "How Many People Have Ever Lived On Earth?", [https://www.prb. org/howmanypeoplehaveeverlivedonearth/], accessed 22 November 2019.

${ }^{32}$ For this contrast in Martin's work, see David Martin, "The Unknown Gods of the English", in idem., The Religious and the Secular, 104-5.

${ }^{33}$ Martin, "Secularization: The Range of Meaning", in idem., The Religious and the Secular, 57.

${ }^{34}$ Martin, "Eliminating the Concept of Secularization", 16

${ }^{35}$ Ibid.

${ }^{36}$ Ibid, $16-17$.

${ }^{37}$ Ibid, 17 .
} 
of religion". ${ }^{38}$ In fact, Martin argued, such a process was sociologically impossible: "there is no steady progress towards a situation in which value systems gradually approximate to the neutral and indisputable deliverances of objective reason". 39 Rather (and here Martin's Durkheimian loyalties came into play) human societies always depend on "ideological systems", because ideology is "required by social cohesion": indeed, "society requires myth" in the sense of "a profoundly coherent framework of meaning". 40 "It is this requirement which the rationalist theory of secularization", with its vision of the rise of post-ideological societies, "ignores", which is why it proclaims a death of collective ideology that is in fact impossible. ${ }^{41}$ In short, Martin was arguing that the idea of "secularization" as the irreversible decline of "religion" was the product of a secular ideological program that defined all other cultures as "religion". ${ }^{42}$ This is why it was essential to realize that the "secularization" story was much more than simply an empirical observation that Western Christianity has declined, but was instead "closely related" to deeply ideological claims about Western societies having experienced "the end of ideology". 43

This was radical criticism, but Martin was too far-reaching a thinker to stop there: in a follow-up essay, "Some Utopian Aspects of the Concept of Secularization", published in 1966, he brought his critique onto a third level, by identifying the real cultural roots of "secular ideology", which mythologized itself as the irresistible outcome of "secularization", in heterodox Christianity. "The simple thesis of this essay", he wrote, "is that secularization is a concept rooted in the ideologies of utopianism, which are themselves derived, with some elements of discontinuity and more important elements of continuity, from the sectarian tradition of Christianity." ${ }^{44}$ In particular, he suggested, Western "secular ideology" was based on two particular "presuppositions derived from Judaism and Christianity". ${ }^{45}$ The first was a stadial view of history, which depicts the human condition as being different at the end than it was in the beginning: but whereas Christianity positions the radical transformation as occurring with the birth of Christ,

\footnotetext{
${ }^{38}$ Ibid, 18. Cf. Bryan Wilson's later definition of "religion" as beliefs and practices pertaining to "the supernatural", and his simultaneous characterisation of "the supernatural" as an "arbitrary presupposition": Bryan Wilson, Religion in Sociological Perspective (Oxford: OUP, 1982), 158-159.

${ }^{39}$ Ibid.

${ }^{40}$ Ibid, 19. For the Durkheimian reference, see Carroll, "David Martin's Theory of Secularization", 21. Indeed, one might go further here, and say that "secularization" in the conventional sense is itself a collective myth in the young Martin's sense.

${ }^{41}$ Martin, "Eliminating the Concept of Secularization", 19.

42 Martin, "Some Utopian Aspects", 24, 25, 35.

${ }^{43} \mathrm{Ibid}, 24,16$. This critique seems directly relevant to Bryan Wilson's contemporaneous claim that "men act less and less in response to religious motivation" because "they assess the world in empirical and rational terms": Wilson, Religion in Secular Society, 3.

${ }^{44}$ Martin, "Some Utopian Aspects", 24.

${ }^{45}$ Ibid, 25.
}

such that Christianity exclusively represents the new era, secular ideologies "shift the crucial epiphany" to the modern period, allowing them to assign Christianity to a past historical "stage", and to identify secularity exclusively with the final stage. ${ }^{46}$ Second, Martin argued, "secular ideology" had borrowed the Christian expectation of ultimate truth being revealed in the end times; but it had relocated this expectation from the distant future to the near future, such that secular ideology considered ultimate truth available in the modern age, hence its proclamation of "the end of ideology". ${ }^{47}$ There were, he added, other continuities, such as the secular intelligentsia taking over the priesthood's function of being the "ontologically privileged strata" and thus the moral guardians of the people. ${ }^{48}$ The secular expectation of humanity's diverse cultures converging on secularity, he argued, also reflected the Christian expectation of peoples of all nations entering heaven. ${ }^{49}$

Finally, if secularization represents the rise of secular ideology, then it remains to explain why this might occur. Martin tackled this problem in two stages, the first of which was denying that secularization was primarily caused by material factors such as economics or technology. Whilst "technological advance will bring about changes of some sort in all institutions, whether religious or otherwise", he argued, anticipating objections to the secularization thesis that would be articulated some thirty years later, "it is not clear that modern technology has a unified impact on religion, either at the level of ecclesiastical organization, dogmatic beliefs, and ritual, or at the level of moral assumptions". ${ }^{50}$ Consequently, he concluded, "most varieties of religion are compatible with industrialised society". After all, he added, tongue firmly in cheek, Catholicism "flourishes... in New York, and other feudal demesnes - like Liverpool". ${ }^{51}$ Second, he insisted in his first book, Pacifism (1965), utopian ideologies like secularity emerge from Christianity during episodes of "radical disorientation", like extreme famine, or, we might suggest in hindsight, the threat of nuclear annihilation during the early Cold War. ${ }^{52}$ It was these profound crises that pushed people to translate Christian expectations of future heavenly blessing into secular stories about future earthly bliss. ${ }^{53}$ Indeed, he

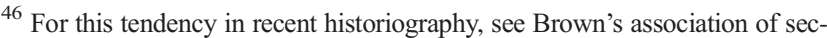
ularity with "the era of postmodernity": Brown, Death of Christian Britain, 176.

${ }^{47}$ Martin, "Some Utopian Aspects", 24-26.

${ }^{48}$ Ibid, 28-30.

${ }^{49}$ Ibid, 25

${ }^{50}$ Ibid, 27-8.

${ }^{51}$ Ibid, 28.

52 David Martin, Pacifism: An Historical and Sociological Study (London: Routledge \& Kegan Paul, 1965), 40. For Martin's identification of secularity as a utopian ideology, see his 1966 essay "Some Utopian Aspects of the Concept of Secularization". For 1958-1962 as the Cold War's "years of maximum danger", see Robert McMahon, The Cold War: A Very Short Introduction (Oxford: OUP, 2003), 79ff.

${ }^{53}$ Martin, Pacifism, 26; Martin, "Some Utopian Aspects", 25.
} 
suggested, this was why it was so crucial to realise that this was precisely what radical Christian theologians such as John Robinson and Harvey Cox, who produced bestselling works on "secularization" in the 1960s, were in fact doing. ${ }^{54}$

If in hindsight we assemble the various dimensions of Martin's critique, the result is a new approach for thinking about Western secularization, which goes as follows. Human societies need collective ideologies, so it is worthwhile defining secular societies in terms of their domination by "secular ideology". 55 "Secular ideology" defines itself as an escape from "religion", and proclaims its own inexorability by defining itself as a historical stage after "religion". A "postsecular" methodology, by contrast (though this term was not available to Martin in the mid-1960s), would concede the fact of Western Christianity's decline, but would conceptualize "secularization" as the rise of "secular ideology", a cultural phenomenon more prompted by profound crises than necessitated by socio-economic development. ${ }^{56}$ It would, moreover, see "secularization" as primarily a local Western phenomenon, because secular ideology has important roots in Western Christianity. ${ }^{57}$ Thirty years before Dipesh Chakrabarty wrote Provincializing Europe, the young Martin had sketched the basic elements of a fully provincialized model of Western secularization. ${ }^{58}$

\section{The Reception of The Religious and the Secular, 1969-2019}

Yet Martin's early essays faced a fundamental problem: they did not simply critique a particular sociological theory, but the entire cultural self-understanding of Western secular societies. ${ }^{59}$ To those living within the culture of secularity, it was simply obvious that "religion" was a real global phenomenon, whose massive decline in "the modern age" had led directly to the post-ideological neutrality of the present-day West; this was a fundamental element of the shared cultural background that implicitly structured their day-to-day lives. ${ }^{60}$ By the late 1960s the ideological claims of the Western secular revolution

\footnotetext{
${ }^{54}$ David Martin, "Sociologist Fallen Among Secular Theologians", in his The Religious and the Secular, 70-78. For this insight pursued in more detail, see Sam Brewitt-Taylor, Christian Radicalism in the Church of England and the Invention of the British Sixties, 1957-1970: The Hope of a World Transformed (Oxford: OUP, 2018).

${ }_{55}$ Martin, "Eliminating the Concept of Secularization", 18-19.

${ }^{56}$ Such a rise is described (although not given this name) in David Martin,

"The Over-Secularized Concept of Man", in idem., The Religious and the Secular, 41

${ }^{57}$ Martin, "Some Utopian Aspects", 24.

${ }^{58}$ Dipesh Chakrabarty, Provincializing Europe: Postcolonial Thought and Historical Difference (Princeton: Princeton University Press, 2001).

59 Jeffrey Cox, "Secularization and Other Master Narratives of Religion in Modern Europe", Kirchliche Zeitgeschichte, Vol. 41, No. 1 (2001): 28-30.

${ }^{60}$ For "background", see Charles Taylor, A Secular Age (Harvard: Belknap, 2007), 13-14
}

were becoming widely internalized, and so it is not surprising that Western scholars much preferred Bryan Wilson's Religion in Secular Society (1966) and the young Berger's The Sacred Canopy (1967); since these works reinforced secular cultures' self-mythology rather than deconstructing it, they were in prime position to lay the foundations for the next two generations of Western secularization scholarship. ${ }^{61}$ These works embedded secularity's claims to exceptional post-ideological neutrality in the very basis of their model, by defining "religion" positively but secularity negatively: Wilson, indeed, began his seminal text by boldly proclaiming that in secular societies, unlike in "religious" societies, people simply "assess the world in empirical and rational terms". ${ }^{62}$ In this ideological context, as Kevin Schulz observed in 2006, "early critics of secularization theory... were mostly ignored." $" 63$ There is a price to pay for being two generations ahead of one's time, and the early essays of Martin's The Religious and the Secular duly paid it. ${ }^{64}$ Even Martin's middle-period work accepted secular theory's fundamental premise that "certain broad tendencies towards secularisation in industrial society have already been fairly well established", whilst nuancing this premise with unprecedented levels of comparative-historical detail. $^{65}$

Yet Martin's early critiques were never entirely forgotten. For a brief moment in the early stages of the secular revolution, they were given a warm welcome by scholars critical of the secularization paradigm. ${ }^{66}$ In the 1980 s and 1990 s, as various minorities of scholars became increasingly disenchanted with that paradigm, they often found themselves returning to Martin's early work. ${ }^{67}$ Nonetheless, even into the early 2000s, most of the major works on Western "secularization" revised the secularization paradigm without overthrowing it. ${ }^{68}$ In 2001, Callum Brown's The Death of Christian Britain radically reimagined mass "secularization" as a revolutionary

\footnotetext{
${ }^{61}$ For Wilson's influence, see Green, Passing of Protestant England, 277; Matthew Grimley, "The Fall and Rise of Church and State? Religious History, Politics and the State in Britain, 1961-2011", Studies in Church History, Vol. 49 (2013): 500.

${ }^{62}$ Wilson, Religion in Secular Society, 3.

${ }^{63}$ Kevin Schulz, "Secularization: A Bibliographic Essay", Hedgehog Review, Vol. 8, Nos. 1-2 (March, 2006): 174.

${ }^{64}$ Cf. Martin, "Secularization and Its Prediction", 33-34.

${ }^{65}$ Martin, "Notes for a General Theory of Secularization", 193; Martin, Secularization, 2.

${ }^{66}$ See for example Larry Shiner, "The Concept of Secularization in Empirical Research", Journal for the Scientific Study of Religion, Vol. 6, No. 2 (Autumn, 1967): 207-220.

${ }^{67}$ See for examples Jeffrey Hadden, "Toward Desacralizing Secularization Theory", Social Forces, Vol. 65, No. 3 (March, 1987): 599; Rodney Stark, "Secularization, R.I.P.", Sociology of Religion, Vol. 60, No. 3 (Autumn, 1999): 254; Keenan, "Post-Secular Sociology", 288-9; Jeffrey Cox, "Provincializing Christendom: The Case of Great Britain", Church History, Vol. 75, No. 1 (March, 2006), 120-130, 124.

${ }^{68}$ A notable exception is Peter Berger (ed.), The Desecularization of the World: Resurgent Religion and World Politics (Eerdmans: Grand Rapids, 1999).
} 
development originating in the 1960 s, whilst retaining the underlying model of "religion" fading into postideological neutrality. ${ }^{69}$ In 2004 , Ronald Inglehart and Pippa Norris retained the familiar secular story of the decline of "religion", merely proposing a new explanatory mechanism based on "existential security". ${ }^{70}$ Even Charles Taylor's A Secular Age (2007), for all its attempt to break out of secular categories, ended up conceptualizing secularization as the gradual decline of the naïve theism supposedly found in late medieval Western societies, leaving behind "secularity 3", a value-neutral arena in which late modern Westerners possess myriad spiritual options. $^{71}$

Since the secularization metanarrative had been deeply embedded in Western culture by the cultural revolution of the $1960 \mathrm{~s}$, Western secularization theory had to wait for Western culture to change before it could experience the kind of radical paradigm-shift demanded by Martin's early critiques. In the early twenty-first century, however, various historical events have begun to initiate such a change. In 2001, the 9/11 attacks on the World Trade Centre abruptly reminded Western commentators that "religion" was still a powerful force in the modern world. ${ }^{72}$ The subsequent rise of postsecular multiculturalism in Anglosphere societies, which guaranteed the rights of specifically "religious" as well as racial minorities, went a step further by underlining the permanent presence of "religion" within Western societies. ${ }^{73}$ A third factor was the rise of China as a global superpower, which reminded self-confident Western commentators that Western modernity was only one amongst many "multiple modernities". ${ }^{74}$ The central factor, though, was the postcolonial turn in Western scholarship, which has announced its determination to "provincialise Europe" and to decentre Western culture and categories. ${ }^{75}$ Whilst these events do not add up to a postsecular revolution in Western societies, they have created a distinctive postsecular movement within the Western academy, and have radically increased

\footnotetext{
$\overline{69}$ Brown, Death of Christian Britain, 193.

${ }^{70}$ Ronald Inglehart and Pippa Norris, Sacred and Secular: Religion and Politics Worldwide (Cambridge: CUP, 2011), 4. This thesis suffers from the significant flaw of overlooking the extent to which inhabitants of Western societies feared nuclear annihilation during the secular revolution of the early 1960s: cf. Ivan Berend, "Gentleman, you must be Mad! Mutually Assured Destruction and Cold War Culture", in Dan Stone, ed., The Oxford Handbook of Postwar European History (Oxford: OUP, 2012).

71 Taylor, A Secular Age, 20-21.

72 Grace Davie, "Religion, Territory, and Choice: Contrasting Configurations, 1970-2015", in David Hempton and Hugh McLeod, eds., Secularization and Religious Innovation in the North Atlantic World (Oxford: OUP, 2017), 312.

73 This was a guiding theme of Jürgen Habermas' influential 2008 "Notes on a Postsecular Society", [http://www.signandsight.com/features/1714.html], accessed 25 November 2019.

74 Cf. Shmuel Eisenstadt, "Multiple Modernities", Daedalus, Vol. 129, No. 1 (Winter, 2000), 1-29.

${ }^{75}$ Cf. Chakrabarty, Provincializing Europe.
}

scholarly discontent with the secularization paradigm. ${ }^{76}$ As Mary Eberstadt put it in 2013, there is now "blood in the water surrounding this matter of secularization theory, and watchful parties on both sides know it". ${ }^{77}$

A revealing index of this trend is the recent growth of interest in Martin's sociology of religion, symbolised by book-length treatments of his work in 2015 and $2018 .^{78}$ In a high-profile 2012 article, the historian J.C.D. Clark announced that the "grand narrative" of "secularization" had straightforwardly "failed", and that "David Martin's challenge in 1965 to dispense with the category 'secularization' should now be re-examined". ${ }^{79}$ Postsecular scholarship has repeatedly found itself returning to Martin's early work for inspiration. ${ }^{80}$ In this exciting new intellectual context, it seems increasingly likely that Martin's early critiques may finally be restored to their rightfully central place in Western secularization theory.

\section{Conclusion}

This article has argued that the "secular revolution" of the 1960s had a powerful impact on Anglophone secularization theory, normalizing the secularization paradigm so thoroughly that alternative perspectives were routinely ignored. The reception accorded to David Martin's The Religious and the Secular (1969) is a central case in point: whereas Martin brilliantly deconstructed the very categories in which secularization theory was expressed, unmasking the very idea of the epochal decline of "religion" as a product of secular ideology, mainstream Western secularization scholarship continued its naïve acceptance of secular categories and secularity's selfmythologization into the early twenty-first century. It is only very recently, following the postcolonial turn in Western historiography, that postsecular historians have begun following in the young Martin's footsteps, and deconstructing the ideological culture of Western secularity in its entirety.

\footnotetext{
${ }^{76}$ Cf. Justin Beaumont, ed., The Routledge Handbook of Postsecularity (Abingdon: Routledge, 2019); Gary Shaw, 'Modernity between Us and Them: The Place of Religion within History', History and Theory Vol. 45, No. 4, (Nov., 2006): 3-4; and the defensive note struck by Detlef Pollack, "Varieties of Secularization Theories and Their Indispensable Core", The Germanic Review, Vol. 90, No. 1 (April, 2015): 60-79.

${ }^{77}$ Mary Eberstadt, How the West Really Lost God: A New Theory of Secularization (West Conshohocken, PA: Templeton Press, 2013), 26.

${ }^{78}$ Dedong Wei and Zhifeng Zhong, eds., Sociology of Religion: A David Martin Reader (Waco: Baylor University Press, 2015); Joas, ed., David Martin and the Sociology of Religion. See also Martin's festschrift: Martyn Percy and Andrew Walker, eds., Restoring the Image: Essays on Religion and Society in Honour of David Martin (Sheffield: Sheffield Academic, 2001).

${ }^{79}$ J.C.D. Clark, "Secularization and Modernization: The Failure of a "Grand Narrative"”, Historical Journal Vol. 55, No. 1 (March, 2012): 193-4.

${ }^{80}$ Keenan, "Post-Secular Sociology", 289; Clayton Fordahl, "The PostSecular: Paradigm-Shift or Provocation?", European Journal of Social Theory, Vol. 20, No. 4 (Nov., 2017): 559.
} 
This story illustrates three wider points about the Western secularization debate. The first is that this debate has been much more influenced by shifting local ideologies than it cares to admit - and indeed than some of its elements are capable of admitting, since the "secularization" metanarrative is itself a story about how Western societies supposedly abandoned collective ideology and embraced post-ideological neutrality. ${ }^{81}$ The second is that these local ideologies have regularly caused this debate to misrepresent its own past, especially by inventing a tradition for the secularization paradigm that includes all the major modern social theorists, a misrepresentation that can only be upheld through the quiet marginalization of dissenting voices, as happened in the young Martin's case. ${ }^{82}$ Finally, however, this episode strongly implies that the recovery of these dissenting voices offers an invaluable resource for historicizing the secular ideology prevalent in late twentieth century Western social theory. ${ }^{83}$ In this respect, as in many others, the dialogue between past and present can provide startlingly alternative ways of thinking about the state of human societies in the twenty-first century.

Open Access This article is licensed under a Creative Commons Attribution 4.0 International License, which permits use, sharing, adaptation, distribution and reproduction in any medium or format, as long as you give appropriate credit to the original author(s) and the source, provide a link to the Creative

\section{Affiliations}

\section{Sam Brewitt-Taylor ${ }^{1}$}

1 Lincoln College, Turl Street, Oxford, OX1 3DR, United Kingdom
Commons licence, and indicate if changes were made. The images or other third party material in this article are included in the article's Creative Commons licence, unless indicated otherwise in a credit line to the material. If material is not included in the article's Creative Commons licence and your intended use is not permitted by statutory regulation or exceeds the permitted use, you will need to obtain permission directly from the copyright holder. To view a copy of this licence, visit http://creativecommons.org/licenses/by/4.0/.

Publisher's Note Springer Nature remains neutral with regard to jurisdictional claims in published maps and institutional affiliations.

Sam Brewitt-Taylor is Darby Fellow in History at Lincoln College, Oxford, where he teaches British and European history since 1815, and researches cultural and religious change in mid-twentieth century Britain. One of David Martin's last scholarly acts was to review his first book, Christian Radicalism in the Church of England and the Invention of the British Sixties, 1957-1970 (Oxford: OUP, 2018) in the Times Literary Supplement (15 March 2019).

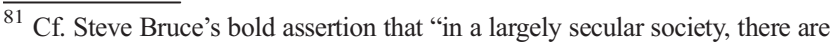
few standpoint obstacles to value-neutrality": Steve Bruce, "A British Perspective on the Critical Sociology of Religion: A Response to Mary Jo Neitz", Critical Research on Religion, Vol. 3, No. 2 (Aug., 2015): 207.

${ }^{82}$ See for example Inglehart and Norris, Sacred and Secular, 3.

${ }^{83}$ The early twenty-first century recovery of the cultural Durkheim is another key example: Jeffrey Alexander and Philip Smith, "Introduction: the New Durkheim", in idem. (eds.), The Cambridge Companion to Durkheim (Cambridge: CUP, 2005), 1-38.
} 